\title{
KAJIAN MACAM DOSIS BIOURINE SAPI DAN PUPUK PHONSKA TERHADAP PERTUMBUHAN DAN PRODUKSI TANAMAN KACANG TANAH (Arachis hypogaea L.)
}

\author{
Dian Eka Kusumawati, Rifki Misbakhul Fauzi, Choirul Anam, dan Mariyatul Qibtiyah \\ Fakultas Pertanian Universitas Islam Darul 'Ulum Lamongan Jawa Timur \\ Korespondensi : dianeka@unisda.ac.id
}

\begin{abstract}
ABSTRAK
Kacang tanah (Arachis hypogaea L.) merupakan tanaman pangan kelompok kacang-kacangan yang memiliki kandungan protein tinggi dan banyak manfaat di berbagai bidang. Baik di bidang kuliner maupun kesehatan. Akan tetapi tingginya manfaat Kacang Tanah ini tidak di dukung dengan produksi yang baik pula, maka dari itu peneliti melakukan penelitian dengan perlakuan Biourine Sapi dan Pupuk Phonska guna meningkatkan produksi tanaman Kacang Tanah. Diduga perlakuan pemberian biourine dengan dosis $7.500 \mathrm{l} / \mathrm{ha}$ dan pupuk phonska $100 \mathrm{~kg} / \mathrm{ha}$ pada masa pertumbuhan dan perkembangan kacang tanah akan memberikan hasil yang lebih baik terhadap produksi kacang tanah. Penelitian ini dilaksanakan di Desa Lamongrejo Kabupaten Lamongan. Penelitian dilaksanakan pada bulan Maret 2019 - Juni 2019. Penelitian ini menggunakan metode RAK Faktorial dengan 3 ulangan, yaitu: Dosis Biourine dan Dosis Pupuk Phonska. Faktor Dosis PGPR terdiri dari: Dosis $3500 \mathrm{l} / \mathrm{ha}$, Dosis $5000 \mathrm{l} /$ ha dan Dosis 7500 I/ha. Faktor Dosis Pupuk Phonska yaitu: Dosis 25 kg/ha, Dosis 50 kg/ha, dan Dosis 100 kg/ha. Parameter yang diamati meliputi tinggi tanaman, jumlah daun, Jumlah polong per tanaman, Jumlah polong bernas per tanaman, Bobot polong per tanaman, Bobot polong bernas per petak, Bobot biji per petak, Berat brangkasan basah, Berat brangkasan kering. Pengamatan dilakukan sampai panen setiap 7 hst mulai tanaman berumur $7 \mathrm{hst}$, dianalisa menggunakan analisa sidik ragam dan dilanjutkan dengan uji BNT 5\%. Dari hasil penelitian melalui analisa sidik ragam disimpulkan bahwa terdapat interaksi pada hampir semua parameter kecuali tinggi tanaman, jumlah daun. Terdapat beda nyata pada perlakuan bobot polong bernas per petak, bobot biji per petak dan berat brangkasan basah. Kombinasi perlakuan terbaik umumnya ditunjukkan oleh perlakuan dosis biourine7500 I/ha dan dosispupukphonska 100 $\mathrm{kg} / \mathrm{ha}$.
\end{abstract}

Kata Kunci : Biourine Sapi, Pupuk Phonska, Kacang Tanah.

\section{ABSTRACT}

Peanuts (Arachis hypogaea L.) are food crops in the group of beans which are the second most important rank after soybeans in their protein content. In terms of the benefits of peanuts for human health it is relatively high, but has not been supported by its production (Pajow et al., 2001). Utilization of peanut products including leaves can be used as animal feed and peanuts can also be processed into oil and food ingredients such as boiled peanuts, tore beans, fried beans, gado-gado spices and satay, peanut tempeh, peanut vegetables etc. The purpose of this study was to determine the types of doses of Biourine Cows and Phonska Fertilizers Against Growth and Production of Peanut Plants. It is assumed that the treatment of biourine with a dose of 7,500 I/ ha and phonska fertilizer $100 \mathrm{~kg} / \mathrm{ha}$ during the growth and development of peanuts will provide a better influence on the growth and production of peanut plants. This research was conducted in Brumbun Hamlet, Lamongrejo Village, Ngimbang District, Lamongan Regency. Place height $\pm 6 \mathrm{~m}$ above sea level (masl). The time of the study was carried out in March 2019 - June 2019. This study used Factorial Randomized Block Design (RBD) with 3 replications, which consisted of 2 factors: Biourine Dosage and Phonska Fertilizer Dosage. Factors The dose of PGPR consists of 3 treatments, namely: Dosage 3500 I / ha, Dosage 5000 I / ha and Dosage 
7500 I / ha. Phonska Fertilizer Dosage Factors consist of 3 treatments, namely: Dosage of $25 \mathrm{~kg} / \mathrm{ha}$, Dosage of $50 \mathrm{~kg} / \mathrm{ha}$, and Dosage of $100 \mathrm{~kg} / \mathrm{ha}$. Parameters observed included plant height, number of leaves, number of pods per plant, number of pithy pods per plant, pod weight per plant, weighted pods per plot, seed weight per plot, wet stover weight, dry stover weight. Observations were carried out until harvest every 7 days starting from 7 days old plants, analyzed using variance analysis and followed by a $5 \%$ LDS test. From the results of research through variance analysis, it was concluded that there were interactions on almost all parameters except plant height, number of leaves. There is a significant difference in the treatment of weighted pods per plot, seed weight per plot and weight of wet stover. The best combination of treatments is generally indicated by the treatment of $7500 \mathrm{I} /$ ha biourine dose and $100 \mathrm{~kg} /$ ha phonska fertilizer dose.

Keyword : Biourine Cow, Phonska Fertilizer, Peanuts.

\section{PENDAHULUAN}

Kacang tanah (Arachis hypogaea L.) merupakan tanaman pangan kelompok kacang-kacangan yang tinggi kandungan proteinnya. Pemanfaatan produk kacang tanah diantaranya adalah daunnya dapat digunakan sebagai pakan ternak, bahan pangan seperti kacang rebus, dan bumbu berbagai masakan (Marzuki, 2007).

Hasil tanaman ditentukan oleh ketersediaan unsur hara baik unsur hara makro seperti $\mathrm{C}, \mathrm{H}, \mathrm{O}, \mathrm{N}, \mathrm{P}, \mathrm{K}, \mathrm{Ca}, \mathrm{Mg}$, dan $\mathrm{S}$ serta unsur hara mikro seperti $\mathrm{Fe}, \mathrm{Zn}, \mathrm{Co}, \mathrm{Mn}, \mathrm{Mo}$, Bo, dan Cl (Gardner, dkk. 1991). Kacang tanah termasuk tanaman leguminosae yang mampu mengikat nitrogen dari udara. Kemampuannya mengikat nitrogen baru dimiliki pada umur 15-20 hari setelah tanam. Pupuk nitrogen tetap diperlukan dengan dosis $15-20 \mathrm{~kg} \mathrm{~N} / \mathrm{ha}$ pada awal pertumbuhan.

Jadi kebutuhan bio-urin untuk mencapai $20 \mathrm{~N} /$ haadalah \pm 5500 liter karena dari hasil analisis bio-urin menunjukkan kandungan $\mathrm{N}$ adalah 0,36 \% (Marzuki, (2007). Menambah ketersediaan unsur hara dengan menggunakan pupuk phonska akan membantu pembentukan bintil akar, dimana unsur nitrogen yang diberikan dalam jumlah minimum dapat menyebabkan penambatan $\mathrm{N}$ oleh Rhizobium maksimum (Anonimous, 2018).

Pemberian pupuk phonska berguna dalam sintesis ATP dan NADPH sebagai suplai energi (Fageria et al, 1997). Selain itu, dosis pupukjuga sangat berpengaruh dalam meningkatkan hasil suatu komoditas pertanian. Dosis pemupukan yang sesuaiakan menghasilkan hasil panen yang maksimal suatu komoditas hasil pertanian.

Apabila dosis pupuk terlalu sedikit, maka tanaman masih kekurangan unsur hara. Dan apabila dosis terlalu banyak maka pupuk tersebut bisa saja menjadi toksin bagi tanaman itu sendiri (Margono, 2009). Hasil penelitian Sutari (2010) menunjukkan bahwa takaran bio-urin sapi sebanyak $7500 \mathrm{l} /$ ha memberikan pertumbuhan dan produksi lebih baik pada kacang tanah, dengan ditunjukkan produksi per petak sebesar $2,73 \mathrm{~kg}$.

Sedangkan dari hasil penelitian (Yudiarsana, 2009) pengaplikasian pupuk kascing kotoran sapi dengan dosis $15 \mathrm{t} /$ ha pada tanaman kedelai, menunjukkan hasil yang maksimal. Penelitian ini untuk mengetahui pengaruh dosis biourine sapi dan pupuk phonska terhadap pertumbuhan dan produksi tanaman Kacang Tanah (Arachis hypogaea L.).

\section{METODE PENELITIAN}

Penelitian ini dilaksanakan di Desa Lamongrejo, Kabupaten Lamongan Maret 2019 - Juni. Ketinggian tempat \pm 6 mdpl. Bahan dan alat yang digunakan adalah benih kacang tanah varietas kelinci, Bio-urin sapi, pupuk phonska, pupuk kimia dan pestisida, cangkul, sabit, pisau, timbangan, meteran, sprayer, gunting, alat-alat tulis dan penunjang lainnya. Penelitian ini menggunakan RAK Faktorial dengan tiga kali ulangan. Faktor pertama Dosis Biourine 
sebanyak 3500 l/ha, 5000 l/ha dan 7500 I/ha. Faktor kedua Dosis Pupuk Phonska dengan takaran sebanyak $25 \mathrm{~kg} / \mathrm{ha}, 50 \mathrm{~kg} / \mathrm{ha}$ dan 100 $\mathrm{kg} / \mathrm{ha}$. Menggunakan petakan sebanyak 27 petak dengan ukuran panjang 1,75 $\mathrm{m}$ dan lebar $1,5 \mathrm{~m}$.

Penanaman dilakukan dengan cara memasukkan benih kacang tanah pada lubang tanam sedalam $\pm 3 \mathrm{~cm}$ dengan jarak tanam antar lubang $25 \mathrm{~cm} \times 25 \mathrm{~cm}$. pupuk yang digunakan diantaranya pupuk Urea $50 \mathrm{~kg} / \mathrm{ha}$, pupuk Phonska dan Biourine. Parameter yang diamatantara lain:

a. Tinggi tanaman dilakukan dengan mengukur mulai dari permukaan tanah sampai pucuk tanaman tertinggi.

b. Jumlah daun dihitung yang sudah membuka sempurna, dan pengamatan dimulai pada tanaman berumur 7,14 , dan 21 hari setelah tanam.

c. Jumlah polong per tanaman dilakukan dengan menghitung semua polong yang terbentuk pada tanaman kacang tanah, dilakukan setelah panen (95 HST).

d. Jumlah polong bernas per tanaman dilakukan dengan menghitung polong yang berisi sempurna pada tanaman kacang tanah. Kegiatan ini dilakukan setelah panen.

e. Bobot polong per tanaman dilakukan dengan menimbang semua polong yang terbentuk, sebelum dilakukan penimbangan polong kacang tanah dibersihkan dari tanah yang melekat. f. Bobot polong bernas per petak dilakukan dengan menimbang semua polong yang terbentuk dan berisi sempurna dalam setiap petak, sebelum dilakukan penimbangan polong kacang tanah dibersihkan dari tanah yang melekat.

g. Bobot biji per petak dilakukan dengan membersihkan biji dari kulit kacang tanah pada tanaman sampel dalam satu petak setelah dijemur atau dikeringkan dengan sinar matahari, kemudian ditimbang.

h. Berat brangkasan basahditimbang tanaman sampel segar dari akar sampai daun yang dibersihkan dari tanah.

i. Berat brangkasan kering ditimbang tanaman sampel yang sudah dikeringkan sinar matahari dari akar sampai daun yang dibersihkan dari tanah.

\section{HASIL DAN PEMBAHASAN}

\section{Tinggi Tanaman}

Tinggi Tanaman Hasil analisa sidik ragam menunjukkan bahwa terdapat beda sangat nyata pada perlakuan macam dosis Phonska, terhadap tinggi tanaman pada umur 7 hst sampai pengamatan umur 28 hst. Rata-rata tertinggi pada perlakuan yaitu dengan dosis 100 $\mathrm{kg} / \mathrm{ha}$, sedangkan rata-rata pertumbuhan kacang tanah terdapat pada perlakuan dengan dosis phonska $25 \mathrm{~kg} / \mathrm{ha}$. Hal ini mengindikasikan bahwa pupuk Phonska sangat baik digunakan untuk meningkatkan jumlah unsur hara di dalam tanah untuk membantu mempercepat pertumbuhan dan tinggi tanaman,

Tabel 1. Rata-rata Tinggi Tanaman Kacang Tanah

\begin{tabular}{ccccc}
\hline \multirow{2}{*}{ Perlakuan } & \multicolumn{4}{c}{ Rata-rata Tinggi Tanaman (cm) } \\
\cline { 2 - 5 } & 7 HST & $14 \mathrm{HST}$ & $21 \mathrm{HST}$ & $28 \mathrm{HST}$ \\
\hline Pupuk Phonska 25 kg/ha & $3,93 \mathrm{a}$ & $9,13 \mathrm{a}$ & $17,40 \mathrm{a}$ & $23,40 \mathrm{a}$ \\
Pupuk Phonska 50 kg/ha & $6,20 \mathrm{~b}$ & $11,93 \mathrm{~b}$ & $19,87 \mathrm{~b}$ & $25,87 \mathrm{~b}$ \\
Pupuk Phonska 100 kg/ha & $7,33 \mathrm{c}$ & $13,13 \mathrm{c}$ & $22,67 \mathrm{c}$ & $28,93 \mathrm{c}$ \\
\hline BNT 5\% & 0,93 & 1,18 & 1,58 & 1,54 \\
\hline
\end{tabular}

Keterangan : Angka-angka yang diikuti oleh huruf yang sama dalam kolom yang sama tidak berbeda nyata pada taraf Uji BNT 5\%.

Sejalan dengan penelitian dari Nusi (2013), menyimpulkan bahwa pertumbuhan tinggi tanaman jagung nampak pada setiap tingkatan perlakuan dosis pupuk phonska yang 
diberikan. Hasil ini menjelaskan bahwa perlakuan pupuk phonska pada umur 28 dan 45 hst dengan dosis $350 \mathrm{~kg} / \mathrm{ha}$ dapat menghasilkan Jumlah Daun

Jumlah Daun Hasil analisa sidik ragam menunjukkan bahwa perlakuan phonska ada beda nyata pada hasil pengamatan umur 14 hst pertumbuhan tinggi tanaman jagung 41,59 dan $111,06 \mathrm{~cm}$.

dan berbeda sangat nyata pada perlakuan macam dosis terhadap jumlah daun umur 21 hst.

Tabel 2. Rata-rata Jumlah Daun Umur 14 hst dan 21 hst.

\begin{tabular}{ccc} 
Perlakuan & $\begin{array}{c}\text { Rata-rata Jumlah Daun Umur 14 } \\
\text { hst }\end{array}$ & $\begin{array}{c}\text { Rata-rata Tinggi Tanaman (cm) } \\
\text { Umur 21 hst }\end{array}$ \\
\hline Pupuk Phonska $25 \mathrm{~kg} / \mathrm{ha}$ & $48,07 \mathrm{a}$ & $131,73 \mathrm{a}$ \\
Pupuk Phonska $50 \mathrm{~kg} / \mathrm{ha}$ & $72,73 \mathrm{~b}$ & $165,60 \mathrm{~b}$ \\
Pupuk Phonska $100 \mathrm{~kg} / \mathrm{ha}$ & $75,33 \mathrm{~b}$ & $175,67 \mathrm{c}$ \\
\hline BNT 5\% & 10,81 & 15,61 \\
\hline
\end{tabular}

Keterangan : Angka-angka yang diikuti oleh huruf yang sama dalam kolom yang sama tidak berbeda nyata pada taraf Uji BNT 5\%.

Pada pengamatan 14 hst perbedaan hasil jumlah daun tidak begitu menonjol dikarenakan pada umur 14 hst bersamaan dengan pengaplikasian perlakuan pada tanaman, pada umur 21 hst perbedaan jumlah daun sudah sangat terlihat, pupuk yang diberikan sudah

Jumlah Polong per Tanaman

Tabel 3. Pengamatan jumlah polong per Tanaman

\begin{tabular}{|c|c|}
\hline Perlakuan & Jumlah Polong per Tanaman (Sampel) \\
\hline Biourine 3500 I/ha, Pupuk Phonska 25 kg/ha & 37,47 a \\
\hline Biourine 3500 I/ha, Pupuk Phonska 50 kg/ha & $38,40 \mathrm{a}$ \\
\hline Biourine $3500 \mathrm{l} / \mathrm{ha}$, Pupuk Phonska $100 \mathrm{~kg} / \mathrm{ha}$ & $38,67 \mathrm{~b}$ \\
\hline Biourine 5000 I/ha, Pupuk Phonska 25 kg/ha & $39,27 c$ \\
\hline Biourine 5000 I/ha, Pupuk Phonska 50 kg/ha & $38,27 \mathrm{a}$ \\
\hline Biourine $5000 \mathrm{l} / \mathrm{ha}$, Pupuk Phonska $100 \mathrm{~kg} / \mathrm{ha}$ & 37,93 a \\
\hline Biourine 7500 I/ha, Pupuk Phonska 25 kg/ha & $38,40 \mathrm{a}$ \\
\hline Biourine 7500 I/ha, Pupuk Phonska 50 kg/ha & $39,07 \mathrm{~b}$ \\
\hline Biourine $7500 \mathrm{l} / \mathrm{ha}$, Pupuk Phonska $100 \mathrm{~kg} / \mathrm{ha}$ & $40,07 d$ \\
\hline BNT 5\% & 0,99 \\
\hline
\end{tabular}

Keterangan : Angka-angka yang diikuti oleh huruf yang sama dalam kolom yang sama tidak berbeda nyata pada taraf Uji BNT 5\%.

Pada Tabel 3. dapat dilihat bahwa jumlah polong terbanyak terdapat pada perlakuan M3P3 yakni perlakuan dengan biourine 7500 liter/ha dan dosis pupuk phonska 100 kg/ha. Pada proses produksi tanaman dibutuhkan banyak sekali nutrisi baik berupa pupuk terlihat bereaksi. Feriawan, et al, (2013), menjelaskan bahwa unsur nitrogen berperan dalam pembelahan dan pemanjangan sel, efektifitas pemberian pupuk NPK akan menambah jumlah daun tanaman. 
perlakuan dosis biourine $3500 \mathrm{l} / \mathrm{ha}$ dan dosis pupuk phonska $25 \mathrm{~kg} / \mathrm{ha}$.

Dari diagnostik penyebab rendahnya produktivitas kacang tanah menurut Sumarno (2003) terdapat sembilan faktor yakni (1) varietas lokal dan campuran yang hasilnya rendah (2) mutu benih rendah, (3) pengolahan tanah dilakukan sangat sederhana, (4)

\section{Jumlah Polong Bernas per Tanaman}

Tabel 4. Pengamatan Jumlah Polong Bernasper Tanaman

\begin{tabular}{|c|c|}
\hline Perlakuan & Jumlah polong bernas per tanaman (sampel) \\
\hline Biourine 3500 I/ha, Pupuk Phonska 25 kg/ha & $32,47 \mathrm{a}$ \\
\hline Biourine 3500 I/ha, Pupuk Phonska 50 kg/ha & 33,27 a \\
\hline Biourine 3500 l/ha, Pupuk Phonska 100 kg/ha & $33,67 \mathrm{~b}$ \\
\hline Biourine 5000 l/ha, Pupuk Phonska 25 kg/ha & $33,87 \mathrm{c}$ \\
\hline Biourine 5000 I/ha, Pupuk Phonska 50 kg/ha & 33,13 a \\
\hline Biourine 5000 l/ha, Pupuk Phonska 100 kg/ha & $32,93 \mathrm{~b}$ \\
\hline Biourine 7500 l/ha, Pupuk Phonska 25 kg/ha & 33,27 a \\
\hline Biourine 7500 I/ha, Pupuk Phonska 50 kg/ha & $33,73 d$ \\
\hline Biourine 7500 l/ha, Pupuk Phonska 100 kg/ha & $34,53 \mathrm{e}$ \\
\hline BNT 5\% & 0,88 \\
\hline
\end{tabular}

Keterangan : Angka-angka yang diikuti oleh huruf yang sama dalam kolom yang sama tidak berbeda nyata pada taraf Uji BNT 5\%.

Pada Tabel 4. dapat dilihat bahwa jumlah polong bernas tertinggi terdapat pada perlakuan M3P3 yakni perlakuan biourine 7500 l/ha dan dosis phonska $100 \mathrm{~kg} / \mathrm{ha}$. Hal ini disebabkan karena lengkapnya kandungan biourine sapi yakni ph 8,33 - 8,35, EC 32,2 $\mathrm{ms} / \mathrm{cm}$, kadar air 2,871 \% (b/b), kandungan $\mathrm{H} 2 \mathrm{O}$ $96,44 \%$, padatan 3,56 \%, C organik 21,29\% padatan, N 1,67 \% padatan, P 2,59\%, K 22,30\%, Na 6,27 \%, Ca 0,47 \%, Mg 1,80 \%. Zn 31,57 ppm, $\mathrm{Cu} 72,12$ ppm.

Sehingga dapat memberikan efek yang baik untuk pertumbuhan tanaman pada fase vegetatif maupun pada fase generatif. Sedangakan kegunaan pupuk phonska sendiri untuk tanaman kacang tanah, yakni menyuplai kandungan bahan organik dalam tanah sangat rendah, (5) ketersediaan hara yang berupa unsur NPK sangat rendah, (6) cekaman kekeringan selama fase generatif, (7) serangan bercak daun dan penyakit karat, (8) terdapat hama seperti ulat, trip, dan empoasca, (9) umur panen belum optimal. . 
Tabel 5. Pengamatan Bobot Polong per Tanaman (Sampel)

\begin{tabular}{lc}
\hline \multicolumn{1}{c}{ Perlakuan } & Bobot Polong per Tanaman (sampel) \\
\hline Biourine 3500 I/ha, Pupuk Phonska $25 \mathrm{~kg} / \mathrm{ha}$ & $40,60 \mathrm{a}$ \\
Biourine 3500 I/ha, Pupuk Phonska $50 \mathrm{~kg} / \mathrm{ha}$ & $41,87 \mathrm{~b}$ \\
Biourine 3500 I/ha, Pupuk Phonska $100 \mathrm{~kg} / \mathrm{ha}$ & $42,13 \mathrm{~b}$ \\
Biourine 5000 I/ha, Pupuk Phonska $25 \mathrm{~kg} / \mathrm{ha}$ & $42,47 \mathrm{~b}$ \\
Biourine 5000 I/ha, Pupuk Phonska $50 \mathrm{~kg} / \mathrm{ha}$ & $42,00 \mathrm{~b}$ \\
Biourine 5000 I/ha, Pupuk Phonska $100 \mathrm{~kg} / \mathrm{ha}$ & $42,27 \mathrm{~b}$ \\
Biourine 7500 I/ha, Pupuk Phonska $25 \mathrm{~kg} / \mathrm{ha}$ & $41,47 \mathrm{a}$ \\
Biourine 7500 I/ha, Pupuk Phonska $50 \mathrm{~kg} / \mathrm{ha}$ & $42,80 \mathrm{c}$ \\
Biourine 7500 I/ha, Pupuk Phonska $100 \mathrm{~kg} / \mathrm{ha}$ & $43,13 \mathrm{~d}$ \\
\hline \multicolumn{1}{c}{ BNT 5\% } & 0,99
\end{tabular}

Keterangan : Angka-angka yang diikuti oleh huruf yang sama dalam kolom yang sama tidak berbeda nyata pada taraf Uji BNT 5\%.

Pada Tabel 5. dapat dilihat bahwa tanaman kacang tanah yang memiliki bobot polong tertinggi terdapat pada perlakuan dosis biourine $7500 \mathrm{I} / \mathrm{ha}$ dan dosis pupuk phonska $100 \mathrm{~kg} / \mathrm{ha}$. Selain dari faktor pupuk dan hpemupukan bobot kacang tanah juga dipengaruhi oleh jenis tanah, kecukupan curah hujan, kedalaman tanah, aerasi tanah, dan ph. Menurut Djaenudin et al. (2003) kacang tanah dapat diproduksi secara optimal pada lahan dengan kisaran kelas kesesuaian dari yang terbaik yakni, struktur tanah ringan, tanah tidak bergumpal, drainase tanah baik, kandungan bahan organik tinggi. Akan tetapi selain itu kesesuaian lahan juga dipengaruhi oleh persyaratan suhu yang optimal selama proses pertumbuhan tanaman.

\section{Bobot Polong Bernas per Petak}

Hasil analisa sidik ragam menunjukan bahwa terdapat sangat berbeda nyata pada perlakuan macam dosis biourine dan pupuk phonska terhadap Bobot bernas kacang tanah per petak (Arachis hypogaea L.)

Tabel 6. Pengamatan Bobot Polong Bernas per Petak (Sampel)

\begin{tabular}{cc}
\hline \multicolumn{1}{c}{ Perlakuan } & Bobot Polong Bernas per Petak (g) \\
\hline Biourine $3500 \mathrm{I} /$ ha & $264,93 \mathrm{a}$ \\
Biourine $5000 \mathrm{I} / \mathrm{ha}$ & $265,87 \mathrm{~b}$ \\
Biourine $7500 \mathrm{I} / \mathrm{ha}$ & $270,60 \mathrm{c}$ \\
\hline BNT 5\% & 0,79 \\
\hline Pupuk Phonska $25 \mathrm{~kg} / \mathrm{ha}$ & $263,40 \mathrm{a}$ \\
Pupuk Phonska $50 \mathrm{~kg} / \mathrm{ha}$ & $267,33 \mathrm{~b}$ \\
Pupuk Phonska $100 \mathrm{~kg} / \mathrm{ha}$ & $270,67 \mathrm{c}$ \\
\hline BNT 5\% & 0,79 \\
\hline
\end{tabular}

Keterangan : Angka-angka yang diikuti oleh huruf yang sama dalam kolom yang sama tidak berbeda nyata pada taraf Uji BNT 5\%.

Data pengamatan bobot polong per petak menunjukkan tidak ada interaksi antara dosis bio urine dengan dosis pupuk Phonska. Namun pada dosis pupuk phonska menunjukkan sangat beda nyata. Feriawan, et al (2013) menyatakan jumlah polong tanaman dipengaruhi oleh dosis pupuk phospor $(\mathrm{P})$ yang diberikan. Tanaman yang dipupuk phospor lebih banyak menghasilkan polong. Semakin banyak polong per tanaman maka akan semakin berat bobot polong yang didapatkan per petak. Secara teoritis pendapat Parnata (Hamidah, 
2009) mengemukakan bahwa untuk memenihi kebutuhan tanaman, kita harus bisa menyediakan unsur hara dalam jumlah yang diperkirakan cukup seimbang.
Bobot Biji per Petak Pengaruh bio urin sapi pada bobot biji per petak nampak pada setiap tingkatan perlakuan dosis bio urin sapi yang diberikan.

\section{Bobot Biji per Petak}

Tabel 7. Pengamatan Bobot Biji per Petak

\begin{tabular}{|c|c|}
\hline Perlakuan & Bobot Biji per Petak (g) \\
\hline Biourine $3500 \mathrm{l} / \mathrm{ha}$ & $180,53 a$ \\
\hline Biourine $5000 \mathrm{l} / \mathrm{ha}$ & $184,33 b$ \\
\hline Biourine $7500 \mathrm{l} / \mathrm{ha}$ & $184,73 b$ \\
\hline BNT 5\% & 1,74 \\
\hline \multicolumn{2}{|c|}{$\begin{array}{l}\text { Keterangan : Angka-angka yang diikuti oleh huruf yang sama dalam kolom yang sama tidak berbeda } \\
\text { nyata pada taraf Uji BNT 5\%. }\end{array}$} \\
\hline $\begin{array}{l}\text { Setiap tanaman yang diberikan } \\
\text { perlakuan berbeda akan mempengaruhi } \\
\text { kandungan hara dalam tanaman tersebut, } \\
\text { tetapi tidak menjamin bahwa semakin besar } \\
\text { dosis yang diberikan akan semakin } \\
\text { meningkatkan pertumbuhan tanaman sebab } \\
\text { tanaman juga memiliki batas dalam penyerapan } \\
\text { hara untuk kebutuhan hidupnya. Menurut }\end{array}$ & $\begin{array}{l}\text { Parnata (2010) penggunaan pupuk cair dari } \\
\text { hewan berupa urin sapi cukup baik untuk } \\
\text { digunakan, namun fungsinya hanya sebagai } \\
\text { pupuk pelengkap bukan untuk pupuk utama. } \\
\text { Hal ini disebabkan kandungan senyawa organik } \\
\text { yang terdapat pada pupuk cair sangat tidak } \\
\text { stabil atau mudah menguap saat musim pada } \\
\text { dan tercuci saat musim hujan. }\end{array}$ \\
\hline
\end{tabular}

\section{Berat Brangkasan Basah dan Brangkasan Kering}

Tabel 8. Pengamatan Berat Brangkasan Basah (g) Perlakuan Berat Brangkasan Basah (g)

\begin{tabular}{cc}
\hline \multicolumn{1}{c}{ Perlakuan } & Berat Brangkasan Basah (gram) \\
\hline Biourine $3500 \mathrm{I} / \mathrm{ha}$ & $219,98 \mathrm{a}$ \\
Biourine $5000 \mathrm{I} / \mathrm{ha}$ & $221,60 \mathrm{~b}$ \\
Biourine $7500 \mathrm{I} / \mathrm{ha}$ & $221,74 \mathrm{c}$ \\
\hline BNT 5\% & 0,43 \\
\hline Pupuk Phonska $25 \mathrm{~kg} / \mathrm{ha}$ & $220,57 \mathrm{a}$ \\
Pupuk Phonska $50 \mathrm{~kg} / \mathrm{ha}$ & $221,01 \mathrm{~b}$ \\
Pupuk Phonska $100 \mathrm{~kg} / \mathrm{ha}$ & $221,74 \mathrm{c}$ \\
\hline BNT 5\% & 0,43 \\
\hline
\end{tabular}

Keterangan : Angka-angka yang diikuti oleh huruf yang sama dalam kolom yang sama tidak berbeda nyata pada taraf Uji BNT 5\%.

Dari Tabel diatas menunjukkan bahwa terdapat beda sangat nyata pada perlakuan macam dosis bio urin sapi dan perlakuan macam dosis Phonska akan tetapi tidak terdapat interaksi antar perlakuan terhadap berat brangkasan basah. Perlakuan dosis bio urin sapi $7500 \mathrm{l} /$ ha dan perlakuan dosis phonska $100 \mathrm{~kg} / \mathrm{ha}$ memberikan hasil terbaik ditunjukkan degan hasil yang lebih tinggi.

Sedangkan pada pengamatan berat braangkasan kering, setelah dilakukan uji BNT hasilnya dapat dilihat sebagai berikut: 
Tabel 9. Pengamatan Berat Brangkasan Kering (g)

\begin{tabular}{lc}
\hline \multicolumn{1}{c}{ Perlakuan } & Berat Brangkasan Kering (g) \\
\hline Biourine $3500 \mathrm{I} / \mathrm{ha}$, Pupuk Phonska $25 \mathrm{~kg} / \mathrm{ha}$ & $32,18 \mathrm{a}$ \\
Biourine $3500 \mathrm{I} / \mathrm{ha}$, Pupuk Phonska $50 \mathrm{~kg} / \mathrm{ha}$ & $33,55 \mathrm{~b}$ \\
Biourine $3500 \mathrm{I} / \mathrm{ha}$, Pupuk Phonska $100 \mathrm{~kg} / \mathrm{ha}$ & $32,92 \mathrm{~b}$ \\
Biourine $5000 \mathrm{I} / \mathrm{ha}$, Pupuk Phonska $25 \mathrm{~kg} / \mathrm{ha}$ & $33,67 \mathrm{c}$ \\
Biourine $5000 \mathrm{I} / \mathrm{ha}$, Pupuk Phonska $50 \mathrm{~kg} / \mathrm{ha}$ & $33,05 \mathrm{~b}$ \\
Biourine $5000 \mathrm{I} / \mathrm{ha}$, Pupuk Phonska $100 \mathrm{~kg} / \mathrm{ha}$ & $33,73 \mathrm{c}$ \\
Biourine $7500 \mathrm{I} / \mathrm{ha}$, Pupuk Phonska $25 \mathrm{~kg} / \mathrm{ha}$ & $33,47 \mathrm{~b}$ \\
Biourine $7500 \mathrm{I} / \mathrm{ha}$, Pupuk Phonska $50 \mathrm{~kg} / \mathrm{ha}$ & $33,75 \mathrm{c}$ \\
Biourine $7500 \mathrm{I} / \mathrm{ha}$, Pupuk Phonska $100 \mathrm{~kg} / \mathrm{ha}$ & $34,13 \mathrm{c}$ \\
\hline BNT $5 \%$ & 0,71 \\
\hline
\end{tabular}

Keterangan : Angka-angka yang diikuti oleh huruf yang sama dalam kolom yang sama tidak berbeda nyata pada taraf Uji BNT 5\%.

Pada Tabel 9. dapat dilihat bahwa rata-rata nilai tertinggi berat brangkasan kering diperoleh dari perlakuan dosis biourin sapi 7500 l/ha dengan dosis Phonska $100 \mathrm{~kg} / \mathrm{ha}$. Berat brangkasan kering digunakan sebagai indikator banyaknya biomassa yang terdapat pada tumbuhan. Sasongko (2010) mengemukakan bahwa biomassa meliputi seluruh bagian tanaman dihasilkan dari proses fotosintesis, serapan hara, dan unsur hara. Bahan kering suatu tanaman merupakan hasil dari semua metabolisme yang berjalan baik akan menghasilkan bahan kering yang besar pula.

\section{KESIMPULAN}

Berdasarkan hasil penelitian terdapat kesimpulan sebagai berikut:

Pengaplikasian dosis biourin sapi 7500 liter/ha dan dosis pupuk phonska 100 kg/ha mendapatkan hasil terbaik dengan rata-rata hasil bobot polong bernas 6,5 ton/ha. Tidak terdapat interaksi pada parameter pengamatan tinggi tanaman, jumlah daun, bobot polong bernas per petak, bobot biji per petak, berat brangkasan basah, akan tetapi terdapat interaksi pada parameter lainnya. Perlakuan biourine berbeda nyata pada parameter bobot polong bernas per sampel, bobot biji per petak, dan berat brangkasan basah. Perlakuan phonska berbeda nyata pada parameter tinggi tanaman, jumlah daun, bobot polong bernas per petak, dan berat brangkasan basah.

\section{DAFTAR PUSTAKA}

Anonimous, 2018. Respon Pemberian Pupuk NPK. AAK. 1989. Kacang Tanah. Penerbit Kanisius. Yogyakarta. 84 hal.

Andrianto, T.T., Indarto, N. 2004. Budidaya dan Analisis Usaha Tani Buncis, Kacang Tanah, Kacang Tunggak. Yogyakarta: Absolut. Adjie, M. M., Quesenberry, K. H., Chamblis, C. G. 2006.

Anonimous, Nitrogen Fixation and Inoculation of Forage Legumes. Agronomy Department. Institute of Food and Agriculture Science. University of Florida. http://edis.ifas.ufl.edu. Diakses 16 Agustus 2019.

Adijaya, I.N., Sudaratmaja, I.G.A.K., Mahaputra, I.K., Trisnawati, N.W., Suharyanto, Guntoro, S., Rinaldi, J., Elizabeth, d.A.A., Priningsih, P.Y., Rachim, A. 2008. Prima Tani LKDRIK Desa Sanggalangit. Denpasar: Balai Pengkajian Teknologi Pertanian Bali. 143 hal. Brown, 1972. 
Growth of The Green Plant. P.153-174. In M.B. Tesar (Ed.). Psysiological Basic of Crop Development. American Society Of America Inc. USA. 341 p. Djaenudin, et al. 2003. Petunjuk Evaluasi Lahan Untuk Komoditas Pertanian. Bogor. Balai Penelitian Tanah, Puslitbang Tanah dan Agroklimat.

Fachruddin, L. $2000 . \quad$ Budidaya Kacang-kacangan. Kanisius. Yogyakarta.

Fageria et al 1997. Fisiologi Tanaman Budidaya. (Penerjemah : Susilo H). UI Press. Jakarta.

Feriawan, et al. 2013. Dampak Pengolahan Tanah dan Pemupukan pada Pertumbuhan dan Hasil Tanaman Kedelai (Glycine max L. Merril) Varietas Tidar. Bone Balango.

Fitria et al. 2016. Dosis Pemupukan NPK Optimal Kacang Tanah pada Tanah Typic Epiaquept. Balai Pengkajian Teknologi Petanian. NTB.

Gardner, EP., Pearce, R.B., and Mitchell. 1991. Physiology of crop Plants. The Lowa State University, Press.

Gaspersz, V. 1991. Metode Perancangan Percobaan. CV. Armico, Bandung.

Goldsworthy and Fisher. 1992. The Physiology of Tropical Field Crops (Terj. Tohari dan Soedaroedjian) "Fisiologi Tanaman Budidaya Tropik" 1992. Gadjah Mada University Press. 874. hal. Yogyakarta.

Hamidah, 2009. Pengaruh Pengendalian Gulma dan Pemberian Pupuk NPK Phonska terhadap Pertumbuhan Tanaman Karet (Hevea brasiliensis Muell Arg.)klon PB 260. Fakultas Pertanian.

$\begin{array}{lr}\text { Universitas } & \text { Widya gama } \\ \text { Mahakam } & \text { Samarinda.ISSN } \\ \text { 2085-3548 } & \end{array}$

Ikhsani, D. 2018. Pertumbuhan Tanaman Kacang tanah (Arachis hypogaea L.) setelah Aplikasi Azotobacter chroococcum dan Pupuk NPK. Fakultas Pertanian. Universitas Padjadjaran Sumedang.ISSN 2580-9636.

Kasno, A., A. Winarto, dan Sunardi. (Eds). 1993. Kacang Tanah. Departemen Pertanian. Badan Penelitian dan Pengembangan Pertanian. Pusat Penelitian dan Pengembangan Tanaman Pangan. Balai Penelitian Tanaman Pangan. Malang. 315 hal. Mapegau. 2007. Pengaruh pupuk nitrogen terhadap pertumbuhan dan hasil tanaman kacang hijau. Jurnal agripura. (3): 2.

Marzuki, R. 2007. Bertanam Kacang Tanah. Jakarta : Penebar Swadaya.

Margono. 2009. Dosis pemupukan. Pusat Penelitian dan Pengembangan Peternakan, Badan Penelitian dan Pengembangan Pertanian.hal. 18-20.

Nusi. R. 2013. Pengaruh pemberian pupuk phonska terhadap pertumbuhan jagung hibrida. Skripsi. Jurusan Agroteknologi. Fakultas Pertanian. Universitas Negeri Gorontalo. Parwati, I.A.P., Sudaratmaja, I.G.A.K., Trisnawati, N.W., Suratmini, P., Suyasa, N., Sunanjaya, W., Budiari, L., Pardi. 2008. Prima Tani di LKDTIB Desa Belanga, Kec. Kintamani, Kab. Bangli, Bali. (laporan). Denpasar: Balai Pengkajian Teknologi Pertanian Bali. 78 hal.

Pajow, dkk. 2001. Paket Teknologi Usaha Tani 
Kacang Tanah Pada Dataran Tinggi di Sulawesi Utara. Proseduring Aplikasi Teknologi Pertanian. BPTP Sulut. HIm 63-73.

Pernata, 2010. Meningkatkan Hasil Panen Dengan Pupuk Organik. Jakarta : Agromedia Pustaka.

Pitojo, S. 2005. Benih Kacang Tanah. Penerbit Kanisius. Yogyakarta. 75 hal. Slamet, 1993. Fisiologis dan Pertumbuhan Kacang Tanah. Dalam Monograf Balai Tanaman Pangan Malang no. 12.

Sumarno. 2003. Teknik Budidaya Kacang Tanah. Sinar Baru Algensindo.

Suprapto, H. S. 2004. Bertanam Kacang Tanah. Penebar Swadaya. Jakarta. 32 hal.

Sutanto, R. 2007. Dasar-Dasar Ilmu Tanah. Konsep dan Kenyataan. Yogyakarta: Kanisius.

Saribun. S Daud. 2008. Pengaruh pupuk majemuk npk pada berbagai dosis terhadap $\mathrm{pH}, \mathrm{p}$-potensial dan p-tersedia serta hasil caysin (brasicca juncea) pada fluventic eutrudepts Jatinangor. Skripsi. Jurusan Ilmu tanah. Fakultas Pertanian. Universitas Padjadjaran. Jatinangor.

Sutari, W. S. 2010. "Uji Kualitas Bio-urine Hasil Fermentasi dengan Mikroba yang Berasal dari Bahan Tanaman Terhadap Pertumbuhan dan Hasil Tanaman Sawi Hijau (Brassica juncea L.)" (tesis). Denpasar : Universitas Udayana. Taiganides, R. E. 1977. Animal Waste. Applied Science Publisher Ltd: London.

Trustinah. 1993. Biologi Kacang Tanah. Hal 9-30. Dalam: A. Kasno, A. Winarto dan Sunardi (Eds.). Kacang Tanah: Monograff Balittan Malang No 12. Balittan. Malang.
Yudiarsana I.M., 2009. "Pengaruh Dosis Pupuk Kascing dan Jarak Tanam Terhadap Pertumbuhan dan Hasil Tanaman Nilam (Pogostemon cablin Benth) di Lahan Kering" (tesis). Denpasar : Universitas Udayana. 